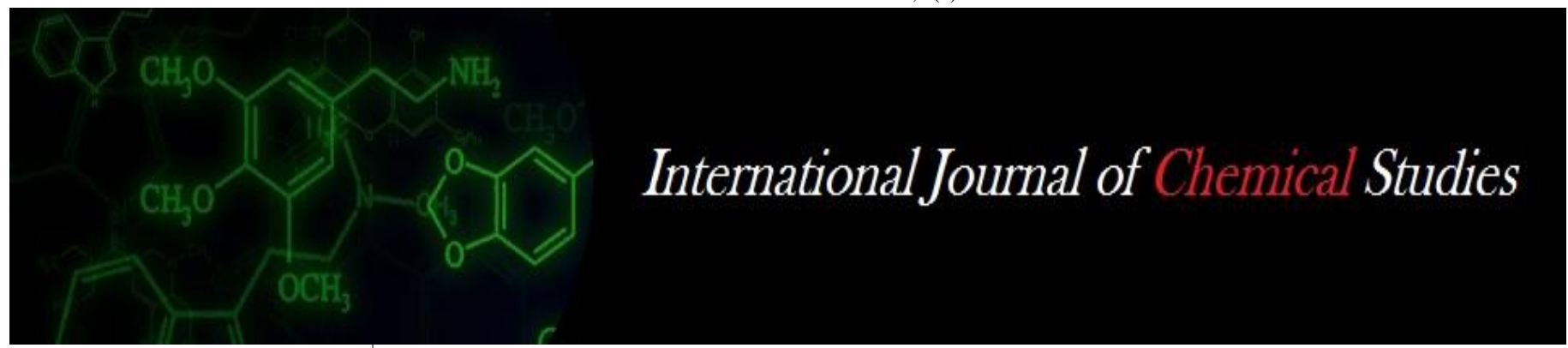

P-ISSN: 2349-8528

E-ISSN: 2321-4902

IJCS 2020; 8(1): 1618-1622

(C) 2020 IJCS

Received: 22-11-2019

Accepted: 24-12-2019

Takhellambam Sanahanbi Devi College of Agriculture, Central Agricultural University, Imphal, Manipur, India

Herojit Singh Athokpam College of Agriculture, Central Agricultural University, Imphal, Manipur, India

K Nandini Devi

College of Agriculture, Central

Agricultural University, Imphal,

Manipur, India

N Surbala Devi

College of Agriculture, Central

Agricultural University, Imphal,

Manipur, India

N Gopimohan Singh

College of Agriculture, Central

Agricultural University, Imphal,

Manipur, India
Corresponding Author:

Takhellambam Sanahanbi Devi College of Agriculture, Central Agricultural University, Imphal, Manipur, India

\section{Integrated nutrient management practices on dry matter production, yield and NPK content of transplanted rice}

\author{
Takhellambam Sanahanbi Devi, Herojit Singh Athokpam, K Nandini \\ Devi, N Surbala Devi and N Gopimohan Singh
}

DOI: https://doi.org/10.22271/chemi.2020.v8.i1w.8493

\begin{abstract}
A field investigation was carried out during kharif seasons of 2016 and 2017 at research farm of College of Agriculture, Central Agricultural University, Imphal, to study the influence of integrated nutrient management on dry matter production, yield and NPK content of transplanted rice. The treatments were laid out in a randomized block design and replicated thrice using the rice variety (CAU-R1). Among the different treatments, higher dry matter production and $\mathrm{N}$ content in rice were found significantly in $\mathrm{T}_{8}$ $\left(100 \%\right.$ RDN from urea +10 tonnes Azolla $\left.\mathrm{ha}^{-1}\right)$ on $30^{\text {th }}, 60^{\text {th }}$ and $90^{\text {th }}$ DAT. At harvest, significantly higher content of $\mathrm{N}$ in grain was observed in $\mathrm{T}_{10}(75 \% \mathrm{RDN}$ from urea $+25 \% \mathrm{RDN}$ from $\mathrm{FYM}+10$ tonnes Azolla ha $^{-1}$ ) while treatments $\mathrm{T}_{8}$ and $\mathrm{T}_{10}$ showed the similar effect in straw $\mathrm{N}$ content. However, statistically higher $\mathrm{P}$ concentration was recorded in $\mathrm{T}_{11}(50 \% \mathrm{RDN}$ from urea $+50 \%$ RDN from FYM + 10 tonnes Azolla $\mathrm{ha}^{-1}$ ) throughout the growing period and also in grain and straw at harvest time. $\mathrm{T}_{12}$ (25\% RDN from urea $+75 \%$ RDN from FYM +10 tonnes Azolla ha $^{-1}$ ) noted the highest K concentration in grain followed by $\mathrm{T}_{11}$ while $\mathrm{K}$ content in straw was highest in both the treatments $\mathrm{T}_{11}$ and $\mathrm{T}_{12}$. In contrary to $\mathrm{P}$ content, the $\mathrm{K}$ content recorded in grain was low under different treatments. Critical analysis of the pooled data showed that soil treated with 75\% RDN from urea + 25\% RDN from FYM + 10 tonnes Azolla ha $^{-1}\left(\mathrm{~T}_{10}\right)$ yielded significantly higher grain and straw yield of rice.
\end{abstract}

Keywords: Integrated nutrient management, dry matter production, NPK content, yield, rice

\section{Introduction}

Rice (Oryza sativa L.) is one of the most popular field crop among other cereals in the world, being cultivated in different agro-ecosystems and serves as the staple food for world's half population $(\mathrm{FAO}, 2004)^{[5]}$. More than $759.6 \mathrm{Mt}$ of rice was produced globally in 2017 (FAO, 2018) ${ }^{[6]}$. India is the world's second largest rice producer (131 million tonnes) after China, with an area of 44 million hectares. The rice productivity in India was $2.98 \mathrm{t} \mathrm{ha}^{-1}$, while the world average is $4.25 \mathrm{t} \mathrm{ha}^{-1}$ (IRRI, 2011). The ever-increasing need for food to satisfy the growing population, rice production must be increased significantly. The increasing demand for rice grain production has to be achieved by using an integration of organic and inorganic fertilizer to maintain the sustainability in crop production. Therefore, more efforts are needed to identify the improved nutrient management strategy for a particular target environment. Appropriate combinations of organic and inorganic nutrient sources enhance the use efficiency of nutrients and ultimately increased the growth and yield attributes of rice. Hence, the present study was initiated to study the integrated nutrient management practices on dry matter production, yield and NPK content of rice.

\section{Materials and Methods}

Field experiments were conducted during kharif seasons of 2016 and 2017 at the research farm of College of Agriculture, Central Agricultural University, Imphal. The soil of the experimental site $\left(24^{\circ} 48^{\prime} 44.50^{\prime}\right.$ ' $\mathrm{N}$ latitude and $93^{\circ} 53^{\prime} 29.98^{\prime} ' \mathrm{E}$ longitude) was clayey in texture having $\mathrm{pH} 5.4$, organic carbon $1.84 \%$, EC $0.19 \mathrm{dSm}^{-1}$, CEC $15.25\left[\mathrm{cmol}(\mathrm{p}+) \mathrm{kg}^{-1}\right.$, available $\mathrm{N} 290.68 \mathrm{~kg} \mathrm{ha}^{-1}$, available $\mathrm{P}_{2} \mathrm{O}_{5} 17.20 \mathrm{~kg} \mathrm{ha}^{-1}$ and available $\mathrm{K}_{2} \mathrm{O} 240.45 \mathrm{~kg} \mathrm{ha}^{-1}$. Rice variety 'CAU-R1' was used as test variety. The experiment was laid out in a randomized block design with three replications and unit plot size being $4 \mathrm{~m} \times 4 \mathrm{~m}$. 
The treatments includes: $\mathrm{T}_{1}=$ Control, $\mathrm{T}_{2}=100 \% \mathrm{RDN}$ from urea, $\mathrm{T}_{3}=100 \%$ RDN from FYM, T $4=20$ tonnes Azolla ha ${ }^{-1}$, $\mathrm{T}_{5}=75 \%$ RDN from urea $+25 \%$ RDN from FYM, $\mathrm{T}_{6}=50 \%$ $\mathrm{RDN}$ from urea $+50 \% \mathrm{RDN}$ from $\mathrm{FYM}, \mathrm{T}_{7}=25 \% \mathrm{RDN}$ from urea $+75 \%$ RDN from FYM, $\mathrm{T}_{8}=100 \% \mathrm{RDN}$ from urea +10 tonnes Azolla ha ${ }^{-1}, \mathrm{~T}_{9}=100 \%$ RDN from FYM + 10 tonnes Azolla ha ${ }^{-1}, \mathrm{~T}_{10}=75 \% \mathrm{RDN}$ from urea $+25 \% \mathrm{RDN}$ from FYM +10 tonnes Azolla ha ${ }^{-1}, \mathrm{~T}_{11}=50 \% \mathrm{RDN}$ from urea $+50 \%$ RDN from FYM +10 tonnes Azolla ha ha $^{-1}$ and $\mathrm{T}_{12}=$ $25 \%$ RDN from urea $+75 \%$ RDN from FYM +10 tonnes Azolla ha-1.

The recommended dose of nitrogen (RDN) i.e. $60 \mathrm{~kg} \mathrm{~N}^{-1}$ was applied as urea and FYM on equivalent nitrogen basis. The total $\mathrm{N}$ content of FYM was $0.54 \%$. A constant dose of $40 \mathrm{~kg} \mathrm{P}_{2} \mathrm{O}_{5} \mathrm{ha}^{-1}$ through $\mathrm{SSP}$ and $30 \mathrm{~kg} \mathrm{~K}_{2} \mathrm{O} \mathrm{ha}^{-1}$ through MOP were applied in all the treatments. Half dose of $\mathrm{N}$, full dose of $\mathrm{P}_{2} \mathrm{O}_{5}$ and two-third of $\mathrm{K}_{2} \mathrm{O}$ were applied as basal dressing before transplanting. The remaining half dose of $\mathrm{N}$ was applied at tillering and panicle initiation stages equally and the remaining one-third of $\mathrm{K}_{2} \mathrm{O}$ was applied at panicle initiation stage. FYM containing equivalent dose of nitrogen was incorporated in the plots as per treatments 15 days prior to transplanting of rice seedlings. Azolla was collected from the surrounding area and intercropped with the rice seven days after transplanting on fresh weight basis. After twenty days of inoculation water was drained out from the field and it was left to decompose. Twenty five days old seedlings were transplanted in the experimental plots maintaining two seedlings per hill and plant spacing of $20 \mathrm{~cm} \times 10 \mathrm{~cm}$.

Plant samples were periodically collected randomly at $30^{\text {th }}$, $60^{\text {th }}$ and $90^{\text {th }}$ days after transplanting (DAT) for study of dry matter yield and nutrients content. Grain and straw yield were recorded at the time of harvest.

Samples were washed properly, then, dried at $65^{\circ} \mathrm{C}$ for 72 hours, powdered and kept for analysis. Total $\mathrm{N}$ content was estimated using the modified micro kjeldahl method as described by Jackson (1973) ${ }^{[10]}$. Di-acid (HNO3: HClO4) extracts of plant samples were subjected to analysis of $\mathrm{P}$ using the vanadomolybdate phosphoric acid yellow colour (Ammonium molybdate + ammonium metavanadate) method and total potassium was determined flame photometrically from the same extract (Jackson, 1973) ${ }^{[10]}$.

\section{Result and Discussion Dry matter production}

Results pertaining to both the consecutive years and pooled mean values (Table 1) revealed that irrespective of different treatments, dry matter yield of paddy increased with advancement of crop growth upto 90 DAT. The results were supported by Singh and Mandal (1997) ${ }^{\text {[22] }}$; Shah and Kumar (2014) ${ }^{[19]}$ and Jeyajothi and Durairaj (2016) ${ }^{[11]}$. In general comparatively higher dry matter yield of paddy was observed in soils amended with inorganic or organic sources of nitrogen applied either singly or in combination over control at different growth stages (Bar et al., 2004; Shah and Kumar, 2014 and Sahu et al., 2015) ${ }^{[4,19,17]}$. The dry matter yield was mainly dependent on mineral $-\mathrm{N}$ status throughout the growing stage, and therefore, on mineralization of organic $\mathrm{N}$ forms, rice crop produced a good amount of dry matter yield. Enhanced agronomic effectiveness of inorganic and organic $\mathrm{N}$ sources was reflected in increased dry matter yield of paddy. The dry matter yield was found in soil treated with $100 \%$ RDN from urea +10 tonnes Azolla ha-1 $\left(\mathrm{T}_{8}\right)$ which was at par with treatments $100 \%$ RDN from urea $\left(\mathrm{T}_{2}\right)$ and $75 \% \mathrm{RDN}$ from urea $+25 \%$ RDN from FYM +10 tonnes Azolla ha ${ }^{-1}$ $\left(\mathrm{T}_{10}\right)$ on 30, 60 and 90 DAT. However, on 90 DAT, these treatments remained at par again with $75 \%$ RDN from urea + $25 \%$ RDN from FYM $\left(\mathrm{T}_{5}\right)$ and $50 \%$ RDN from urea $+50 \%$ RDN from FYM $\left(\mathrm{T}_{6}\right)$ amended soil followed by soil treated with $50 \%$ RDN from urea $+50 \%$ RDN from FYM +10 tonnes Azolla ha-1 $\left.\mathrm{T}_{11}\right)$ showing similarity effects with the remaining $\mathrm{N}$ treatments except soil incorporated with 20 tonnes Azolla ha-1 $\left(\mathrm{T}_{4}\right)$. Higher dry matter production might be due to increased availability of major nutrients through chemical fertilizer and mineralized nutrient from organic sources throughout the cropping period (Jeyajothi and Durairaj, 2016) ${ }^{[11]}$. This leads to enhancement of proficient growth and development of rice through highest uptake and utilization of the nutrients.

Table 1: Effect of Integrated nutrient management on dry matter production, grain and straw yield of Rice

\begin{tabular}{|c|c|c|c|c|c|c|c|c|c|c|c|c|c|c|c|}
\hline \multirow{3}{*}{ Treatments } & \multicolumn{9}{|c|}{ Dry matter production $\left(\mathrm{kg} \mathrm{ha}^{-1}\right)$} & \multirow{2}{*}{\multicolumn{3}{|c|}{ Grain yield $\left(\mathrm{kg} \mathrm{ha}^{-1}\right)$}} & \multirow{2}{*}{\multicolumn{3}{|c|}{ Straw yield $\left(\mathrm{kg} \mathrm{ha}^{-1}\right)$}} \\
\hline & \multicolumn{3}{|c|}{ 30 ${ }^{\text {th }}$ DAT } & \multicolumn{3}{|c|}{$60^{\text {th }}$ DAT } & \multicolumn{3}{|c|}{$90^{\text {th }}$ DAT } & & & & & & \\
\hline & 2016 & 2017 & Pooled & 2016 & 2017 & Pooled & 2016 & 2017 & Pooled & 2016 & 2017 & Pooled & 2016 & 2017 & Pooled \\
\hline $\mathrm{T}_{1}$ & 1771.00 & 1743.00 & 1757.00 & 5400.50 & 5243.00 & 5321.75 & 7605.50 & 7360.50 & 7483.00 & 3539.58 & 3233.00 & 3386.29 & 4395.33 & 4202.67 & 4299.00 \\
\hline $\mathrm{T}_{2}$ & 2513.00 & 2460.50 & 2486.75 & 6940.50 & 7010.50 & 6975.50 & 10318.00 & 10206.00 & 10262.00 & 4922.02 & 4832.00 & 4877.01 & 6425.00 & 6476. & 6450.50 \\
\hline $\mathrm{T}_{3}$ & 1914.50 & 1946.00 & 1930.25 & 6062.00 & 5855.50 & 5958.75 & 8988.00 & 9037.00 & 9012.50 & 433 & 421 & 427 & 531 & 5407.69 & 5362.53 \\
\hline $\mathrm{T}_{4}$ & 1960.00 & 1953.00 & 1956.50 & 6034.00 & 5943.00 & 5988.50 & 8911.00 & 8911.00 & 8911.00 & & 3913.17 & 4007.92 & 5293 & 5224 & 5258.86 \\
\hline $\mathrm{T}_{5}$ & 2317.00 & 2387.00 & 2352.00 & 6818.00 & 6905.50 & 6861.75 & 10157.00 & 10122.00 & 101 . & & 5069.54 & 5106.10 & & 6520.00 & 6368.33 \\
\hline $\mathrm{T}_{6}$ & 2215.50 & 2373.00 & 2294.25 & 6692.00 & 6692.00 & 6692.00 & 10083.50 & 10031.00 & 1005 & 49 & 4462.53 & 4686.76 & 621 & 5946 & 6080.29 \\
\hline $\mathrm{T}_{7}$ & 2093.00 & 2093.00 & 2093.00 & 6594.00 & 6482.00 & 6538.00 & \begin{tabular}{|l|}
9996.00 \\
\end{tabular} & 9828.00 & 9912.00 & 4848.00 & 4563.37 & 4705.68 & 573 & 5900 & 5815.63 \\
\hline $\mathrm{T}_{8}$ & 2565.50 & 2548.00 & 2556.75 & 6993. & 7073. & 7033.25 & 10377.50 & 10335.50 & 10356.50 & 5024.33 & 4948.79 & 4986 & & 6392 & 6441.83 \\
\hline $\mathrm{T}_{9}$ & 1953.00 & 1998.50 & 1975.75 & 6412.00 & 6464.50 & 6438.25 & 9688.00 & 9786.00 & \begin{tabular}{|l|}
9737.00 \\
\end{tabular} & 4473 & 4423.28 & 4448 & 557 & 559 & 5587.74 \\
\hline $\mathrm{T}_{10}$ & 2436.00 & 2530.50 & 2483.25 & 6874.00 & 7028.00 & 6951.00 & 10223.50 & 10265.50 & 10244.50 & 5294.00 & 5436.10 & 5365.05 & 6541.67 & 6583.00 & 6562.33 \\
\hline $\mathrm{T}_{11}$ & 2177.00 & 2215.50 & 2196.25 & 6594.00 & 6580.00 & 6587.00 & 9996.00 & \begin{tabular}{|l|}
9947.00 \\
\end{tabular} & 9971.50 & 5223.33 & 5079.01 & 5151.17 & 6275.00 & 6476.00 & 6375.50 \\
\hline$T_{12}$ & 2149.00 & 2215.50 & 2182.25 & 6492.50 & 6492.50 & 6492.50 & 9740.50 & \begin{tabular}{|l|}
9828.00 \\
\end{tabular} & 9784.25 & 4850.00 & 4727.67 & 4788.83 & 5920.83 & 6258.00 & 6089.42 \\
\hline $\operatorname{SEd}( \pm)$ & 61.69 & 62.04 & \begin{tabular}{|l|}
43.34 \\
\end{tabular} & 118.94 & 118.34 & 82.67 & \begin{tabular}{|l|}
239.47 \\
\end{tabular} & 238.30 & \begin{tabular}{|l|}
154.51 \\
\end{tabular} & \begin{tabular}{|l|}
141.36 \\
\end{tabular} & 122.12 & \begin{tabular}{|c|}
95.97 \\
\end{tabular} & \begin{tabular}{|l|}
198.82 \\
\end{tabular} & 271.96 & 161.81 \\
\hline $\mathrm{CD}(\mathrm{p}=0.05)$ & 127.93 & 128.66 & 86.86 & 246.67 & 245.42 & 165.67 & 496.64 & 494.21 & 309.65 & 293.17 & 253.26 & 192.32 & 412.32 & 564.00 & 324.27 \\
\hline
\end{tabular}

\section{Grain and straw yield}

Significantly higher grain and straw yield of paddy were found in soil treated with inorganic and organic sources of nitrogen and their combinations over untreated control (Table 2). Similar reports on higher yield due to application of inorganic and organic $\mathrm{N}$ sources applied either singly or in combination were reported earlier by Husan et al. (2014); Islam et al. (2014); Sohel et al. (2016) and Kumar et al. (2018) ${ }^{[8,9,23,12]}$. Pooled mean values showed that soil treated with $75 \%$ RDN from urea $+25 \%$ RDN from FYM +10 tonnes Azolla ha $^{-1}\left(\mathrm{~T}_{10}\right)$ yielded significantly higher grain and straw yield followed by $50 \%$ RDN from urea $+50 \%$ RDN 
from FYM + 10 tonnes Azolla ha ${ }^{-1}\left(\mathrm{~T}_{11}\right)$ showing parity with $\mathrm{T}_{8}$ and $\mathrm{T}_{5}$ on grain yield. However, $\mathrm{T}_{10}$ remained at par with $100 \%$ RDN from urea $\left(\mathrm{T}_{2}\right), 75 \%$ RDN from urea $+25 \%$ RDN from FYM $\left(\mathrm{T}_{5}\right)$ and $50 \% \mathrm{RDN}$ from urea $+50 \% \mathrm{RDN}$ from $\mathrm{FYM}+10$ tonnes Azolla ha $^{-1}\left(\mathrm{~T}_{11}\right)$ on straw yield. Comparing between the sole application of inorganic and organic sources of $\mathrm{N}$, significantly higher amount of grain and straw yield were observed in inorganic $\mathrm{N}$ treated soil $\left(\mathrm{T}_{2}\right)$ than organic sources $\left(\mathrm{T}_{3}\right.$ and $\left.\mathrm{T}_{4}\right)$. The increased grain and straw yield due to combined application of organic manures and urea was mainly attributed to overall improvement in soil fertility including $\mathrm{N}$ supply (Azam, 1990) ${ }^{[2]}$. Crop yield depend mainly on the availability of $\mathrm{NH}_{4}{ }^{+}-\mathrm{N}$ in submerged condition. Organic manures alone or with urea $\mathrm{N}$ supply $\mathrm{NH}_{4}{ }^{+}-\mathrm{N}$ to the plant through continuous mineralization of organic $\mathrm{N}$ increasing $\mathrm{N}$ supply and ultimately giving higher grain and straw yield. This revealed the production efficiency of organic sources of nutrients due to improved soil fertility levels (Satish et al., 2011 and Aditya and Kushwaha, 2018) ${ }^{[18,1] .}$ Application of urea $\mathrm{N}$ produced higher yield than organic manures alone might be due to inability of organic $\mathrm{N}$ sources to release nutrients at peak requirement of the crop.

Table 2: Effect of Integrated nutrient management on $\mathrm{N}$ content (\%) in rice

\begin{tabular}{|c|c|c|c|c|c|c|c|c|c|c|c|c|c|c|c|c|}
\hline & \multicolumn{3}{|c|}{ 30 DAT } & \multicolumn{3}{|c|}{ 60 DAT } & \multicolumn{3}{|c|}{ 90 DAT } & \multicolumn{3}{c|}{ Grain } & Straw & \\
\hline Treatments & $\mathbf{2 0 1 6}$ & $\mathbf{2 0 1 7}$ & Pooled & $\mathbf{2 0 1 6}$ & $\mathbf{2 0 1 7}$ & Pooled & $\mathbf{2 0 1 6}$ & $\mathbf{2 0 1 7}$ & Pooled & $\mathbf{2 0 1 6}$ & $\mathbf{2 0 1 7}$ & Pooled & $\mathbf{2 0 1 6}$ & $\mathbf{2 0 1 7}$ & Pooled \\
\hline $\mathrm{T}_{1}$ & 0.98 & 0.96 & 0.97 & 1.08 & 1.05 & 1.07 & 1.06 & 1.02 & 1.04 & 1.02 & 1.02 & 1.02 & 0.38 & 0.37 & 0.38 \\
\hline $\mathrm{T}_{2}$ & 1.32 & 1.29 & 1.31 & 1.89 & 1.81 & 1.85 & 1.51 & 1.50 & 1.51 & 1.44 & 1.42 & 1.43 & 0.65 & 0.64 & 0.65 \\
\hline $\mathrm{T}_{3}$ & 1.13 & 1.13 & 1.13 & 1.25 & 1.28 & 1.27 & 1.18 & 1.20 & 1.19 & 1.29 & 1.30 & 1.30 & 0.56 & 0.57 & 0.57 \\
\hline $\mathrm{T}_{4}$ & 1.10 & 1.08 & 1.09 & 1.17 & 1.22 & 1.20 & 1.13 & 1.16 & 1.15 & 1.25 & 1.27 & 1.26 & 0.54 & 0.55 & 0.55 \\
\hline $\mathrm{T}_{5}$ & 1.28 & 1.27 & 1.28 & 1.59 & 1.60 & 1.60 & 1.48 & 1.50 & 1.49 & 1.44 & 1.37 & 1.41 & 0.63 & 0.63 & 0.63 \\
\hline $\mathrm{T}_{6}$ & 1.22 & 1.23 & 1.23 & 1.50 & 1.55 & 1.53 & 1.27 & 1.28 & 1.28 & 1.37 & 1.37 & 1.37 & 0.61 & 0.61 & 0.61 \\
\hline $\mathrm{T}_{7}$ & 1.17 & 1.16 & 1.17 & 1.37 & 1.37 & 1.37 & 1.24 & 1.26 & 1.25 & 1.35 & 1.34 & 1.35 & 0.60 & 0.61 & 0.61 \\
\hline $\mathrm{T}_{8}$ & 1.36 & 1.32 & 1.34 & 2.03 & 1.87 & 1.95 & 1.58 & 1.57 & 1.58 & 1.45 & 1.44 & 1.45 & 0.68 & 0.67 & 0.68 \\
\hline $\mathrm{T}_{9}$ & 1.14 & 1.15 & 1.15 & 1.29 & 1.31 & 1.30 & 1.21 & 1.23 & 1.22 & 1.31 & 1.32 & 1.32 & 0.56 & 0.58 & 0.57 \\
\hline $\mathrm{T}_{10}$ & 1.32 & 1.35 & 1.34 & 1.97 & 1.87 & 1.92 & 1.58 & 1.54 & 1.56 & 1.48 & 1.46 & 1.47 & 0.66 & 0.67 & 0.67 \\
\hline $\mathrm{T}_{11}$ & 1.23 & 1.25 & 1.24 & 1.60 & 1.62 & 1.61 & 1.48 & 1.48 & 1.48 & 1.39 & 1.40 & 1.40 & 0.62 & 0.63 & 0.63 \\
\hline $\mathrm{T}_{12}$ & 1.18 & 1.16 & 1.17 & 1.39 & 1.42 & 1.41 & 1.29 & 1.29 & 1.29 & 1.37 & 1.35 & 1.36 & 0.61 & 0.62 & 0.62 \\
\hline $\mathrm{SEd}( \pm)$ & 0.03 & 0.03 & 0.02 & 0.04 & 0.03 & 0.05 & 0.03 & 0.03 & 0.02 & 0.03 & 0.03 & 0.02 & 0.01 & 0.01 & 0.01 \\
\hline $\mathrm{CD}(\mathrm{p}=0.05)$ & 0.05 & 0.05 & 0.04 & 0.07 & 0.07 & 0.10 & 0.06 & 0.06 & 0.04 & 0.06 & 0.06 & 0.04 & 0.03 & 0.03 & 0.02 \\
\hline
\end{tabular}

\section{Nitrogen content}

$\mathrm{N}$ content in the plant in both the years of the experiment and pooled data followed similar pattern. $\mathrm{N}$ content was increased on 60 day followed by a declining trend on 90 DAT. The periodical declining trend of $\mathrm{N}$ content in plants with rice crop stage advancement was in agreement with Shinde et al. (2017) ${ }^{[21]}$ and Meetei et al. (2019) ${ }^{[15]}$. It was attributed to dilution factor. Regardless of different sampling days, application of either inorganic, organic or their combinations significantly increased the $\mathrm{N}$ concentration over the untreated control under different sampling days. Grain and straw also observed the significantly higher $\mathrm{N}$ content with $\mathrm{N}$ treatments than control. The finding was also given by Nongmeikapam and Devi, $2018^{[16]}$ and Meetei et al., $2019^{[15]}$. The pooled data revealed that statistically higher $\mathrm{N}$ content was observed in $\mathrm{T}_{8}$ on 30,60 and 90 DAT which was at par with $\mathrm{T}_{2}$ and $\mathrm{T}_{10}$ and only with $\mathrm{T}_{10}$ on 90 DAT. At harvest significantly higher content of $\mathrm{N}$ in grain was observed in $\mathrm{T}_{10}$ showing parity to $\mathrm{T}_{8}$ and $T_{2}$. Similar effect of treatments $T_{8}$ and $T_{10}$ in straw $N$ content was also recorded. The improvement in $\mathrm{N}$ content in organic treatment along with inorganic source might be slow release of nutrients to the soil along with inorganic source and made it available throughout the growing period (Helgason et al., 2007; Baitilwake et al., 2012 and Meetei et al., 2019) ${ }^{[7,3,}$ 15].

\section{Phosphorus content}

A decreasing trend in $\mathrm{P}$ content (Table 3) in rice with increased in crop growth in both the years as well as in pooled. P content decline with crop growth advancement was also observed by Liu and Zhu (1996) ${ }^{[14]}$; Latha et al. (2019) ${ }^{[13]}$ and Meetei et al. (2019) ${ }^{[15]}$. The decrease in P content with the advancement of crop growth might be due to three reasons: dilution effect, caused by higher dry matter production, low $\mathrm{P}$ status of soil or fixation of applied $\mathrm{P}$ (Meetei et al., 2019) ${ }^{[15]}$. Significantly higher $\mathrm{P}$ accumulation was recorded in all $\mathrm{N}$ treatments than control. Similar finding on higher concentration of $\mathrm{P}$ in rice crop was earlier given by Shinde et al. (2017) ${ }^{[21]}$; Latha et al. (2019) ${ }^{[13]}$ and Meetei et al. (2019) ${ }^{[15]}$. The increased $\mathrm{P}$ content might be due to gradual release of nutrients from organic sources thereby increasing soil nutrients along with inorganic source and made available during the growing season. Decline in $\mathrm{P}$ content with advancement of crop growth was found in all the treatments. Comparing among the different treatments, significantly higher $\mathrm{P}$ concentration was recorded in $\mathrm{T}_{11}$ throughout the growing periods and also in grain and straw at harvest time. It was also observed that $T_{11}, T_{6}$ and $T_{10}$ remained statistically at par on $\mathrm{P}$ content in grain of rice.

Table 3: Effect of Integrated nutrient management on $\mathrm{P}$ content (\%) in rice

\begin{tabular}{|c|c|c|c|c|c|c|c|c|c|c|c|c|c|c|c|}
\hline & \multicolumn{3}{|c|}{ 30 DAT } & \multicolumn{3}{c|}{ 60 DAT } & \multicolumn{3}{c|}{ 90 DAT } & \multicolumn{3}{c|}{ Grain } & & Straw & \\
\hline Treatments & $\mathbf{2 0 1 6}$ & $\mathbf{2 0 1 7}$ & Pooled & $\mathbf{2 0 1 6}$ & $\mathbf{2 0 1 7}$ & Pooled & $\mathbf{2 0 1 6}$ & $\mathbf{2 0 1 7}$ & Pooled & $\mathbf{2 0 1 6}$ & $\mathbf{2 0 1 7}$ & Pooled & $\mathbf{2 0 1 6}$ & $\mathbf{2 0 1 7}$ & Pooled \\
\hline $\mathrm{T}_{1}$ & 0.11 & 0.09 & 0.10 & 0.06 & 0.05 & 0.06 & 0.03 & 0.03 & 0.03 & 0.23 & 0.20 & 0.22 & 0.07 & 0.05 & 0.06 \\
\hline $\mathrm{T}_{2}$ & 0.23 & 0.22 & 0.23 & 0.15 & 0.13 & 0.14 & 0.10 & 0.09 & 0.10 & 0.27 & 0.25 & 0.26 & 0.12 & 0.11 & 0.12 \\
\hline $\mathrm{T}_{3}$ & 0.16 & 0.17 & 0.17 & 0.11 & 0.11 & 0.11 & 0.06 & 0.07 & 0.07 & 0.26 & 0.26 & 0.26 & 0.11 & 0.11 & 0.11 \\
\hline $\mathrm{T}_{4}$ & 0.14 & 0.16 & 0.15 & 0.10 & 0.08 & 0.09 & 0.06 & 0.06 & 0.06 & 0.25 & 0.24 & 0.25 & 0.11 & 0.09 & 0.10 \\
\hline $\mathrm{T}_{5}$ & 0.23 & 0.20 & 0.22 & 0.15 & 0.13 & 0.14 & 0.09 & 0.10 & 0.10 & 0.34 & 0.30 & 0.32 & 0.15 & 0.14 & 0.15 \\
\hline $\mathrm{T}_{6}$ & 0.26 & 0.24 & 0.25 & 0.20 & 0.16 & 0.18 & 0.13 & 0.13 & 0.13 & 0.37 & 0.32 & 0.35 & 0.17 & 0.18 & 0.18 \\
\hline $\mathrm{T}_{7}$ & 0.20 & 0.22 & 0.21 & 0.16 & 0.14 & 0.15 & 0.14 & 0.12 & 0.13 & 0.33 & 0.30 & 0.32 & 0.15 & 0.14 & 0.15 \\
\hline
\end{tabular}




\begin{tabular}{|c|c|c|c|c|c|c|c|c|c|c|c|c|c|c|c|}
\hline $\mathrm{T}_{8}$ & 0.26 & 0.22 & 0.24 & 0.16 & 0.16 & 0.16 & 0.13 & 0.12 & 0.13 & 0.30 & 0.31 & 0.31 & 0.17 & 0.17 & 0.17 \\
\hline $\mathrm{T}_{9}$ & 0.18 & 0.19 & 0.19 & 0.13 & 0.12 & 0.13 & 0.08 & 0.08 & 0.08 & 0.28 & 0.29 & 0.29 & 0.13 & 0.13 & 0.13 \\
\hline $\mathrm{T}_{10}$ & 0.27 & 0.25 & 0.26 & 0.21 & 0.18 & 0.20 & 0.17 & 0.15 & 0.16 & 0.39 & 0.35 & 0.37 & 0.18 & 0.19 & 0.19 \\
\hline $\mathrm{T}_{11}$ & 0.29 & 0.26 & 0.28 & 0.24 & 0.24 & 0.24 & 0.19 & 0.21 & 0.20 & 0.42 & 0.36 & 0.39 & 0.21 & 0.21 & 0.21 \\
\hline $\mathrm{T}_{12}$ & 0.21 & 0.25 & 0.23 & 0.21 & 0.23 & 0.22 & 0.16 & 0.17 & 0.17 & 0.35 & 0.32 & 0.34 & 0.18 & 0.17 & 0.18 \\
\hline $\mathrm{SE}(\mathrm{d}) \pm$ & 0.01 & 0.01 & 0.02 & 0.01 & 0.01 & 0.01 & 0.01 & 0.01 & 0.01 & 0.01 & 0.01 & 0.01 & 0.003 & 0.003 & 0.01 \\
\hline $\mathrm{CD}(\mathrm{p}=0.05)$ & 0.02 & 0.02 & 0.04 & 0.01 & 0.02 & 0.03 & 0.01 & 0.01 & 0.02 & 0.01 & 0.01 & 0.04 & 0.01 & 0.01 & 0.02 \\
\hline
\end{tabular}

Table 4: Effect of INM on K content (\%) in rice at different growth stages

\begin{tabular}{|c|c|c|c|c|c|c|c|c|c|c|c|c|c|c|c|c|c|}
\hline & \multicolumn{3}{|c|}{ 30 DAT } & \multicolumn{3}{c|}{ 60 DAT } & \multicolumn{3}{c|}{ 90 DAT } & \multicolumn{3}{c|}{ Grain } & Straw & \\
\hline Treatments & $\mathbf{2 0 1 6}$ & $\mathbf{2 0 1 7}$ & Pooled & $\mathbf{2 0 1 6}$ & $\mathbf{2 0 1 7}$ & Pooled & $\mathbf{2 0 1 6}$ & $\mathbf{2 0 1 7}$ & Pooled & $\mathbf{2 0 1 6}$ & $\mathbf{2 0 1 7}$ & Pooled & 2016 & 2017 & Pooled \\
\hline $\mathrm{T}_{1}$ & 1.31 & 1.28 & 1.30 & 1.28 & 1.25 & 1.27 & 1.17 & 1.15 & 1.16 & 0.27 & 0.24 & 0.26 & 1.06 & 1.03 & 1.05 \\
\hline $\mathrm{T}_{2}$ & 1.60 & 1.60 & 1.60 & 1.43 & 1.36 & 1.40 & 1.25 & 1.22 & 1.24 & 0.33 & 0.33 & 0.33 & 1.21 & 1.23 & 1.22 \\
\hline $\mathrm{T}_{3}$ & 1.59 & 1.60 & 1.60 & 1.44 & 1.40 & 1.42 & 1.26 & 1.25 & 1.26 & 0.34 & 0.33 & 0.34 & 1.23 & 1.25 & 1.24 \\
\hline $\mathrm{T}_{4}$ & 1.59 & 1.60 & 1.60 & 1.43 & 1.38 & 1.41 & 1.24 & 1.23 & 1.24 & 0.34 & 0.34 & 0.34 & 1.21 & 1.24 & 1.23 \\
\hline $\mathrm{T}_{5}$ & 1.63 & 1.65 & 1.64 & 1.45 & 1.45 & 1.45 & 1.35 & 1.28 & 1.32 & 0.36 & 0.37 & 0.37 & 1.25 & 1.25 & 1.25 \\
\hline $\mathrm{T}_{6}$ & 1.65 & 1.66 & 1.66 & 1.48 & 1.48 & 1.48 & 1.32 & 1.31 & 1.32 & 0.38 & 0.38 & 0.38 & 1.30 & 1.26 & 1.28 \\
\hline $\mathrm{T}_{7}$ & 1.66 & 1.76 & 1.71 & 1.51 & 1.52 & 1.52 & 1.32 & 1.33 & 1.33 & 0.39 & 0.40 & 0.40 & 1.28 & 1.28 & 1.28 \\
\hline $\mathrm{T}_{8}$ & 1.63 & 1.65 & 1.64 & 1.45 & 1.43 & 1.44 & 1.31 & 1.27 & 1.29 & 0.35 & 0.33 & 0.34 & 1.25 & 1.24 & 1.25 \\
\hline $\mathrm{T}_{9}$ & 1.60 & 1.61 & 1.61 & 1.42 & 1.41 & 1.42 & 1.28 & 1.26 & 1.27 & 0.33 & 0.35 & 0.34 & 1.25 & 1.25 & 1.25 \\
\hline $\mathrm{T}_{10}$ & 1.90 & 1.72 & 1.81 & 1.51 & 1.47 & 1.49 & 1.37 & 1.30 & 1.34 & 0.38 & 0.38 & 0.38 & 1.28 & 1.30 & 1.29 \\
\hline $\mathrm{T}_{11}$ & 1.90 & 1.92 & 1.91 & 1.53 & 1.50 & 1.52 & 1.42 & 1.38 & 1.40 & 0.39 & 0.40 & 0.40 & 1.32 & 1.31 & 1.32 \\
\hline $\mathrm{T}_{12}$ & 1.92 & 1.91 & 1.92 & 1.51 & 1.52 & 1.52 & 1.38 & 1.36 & 1.37 & 0.42 & 0.43 & 0.43 & 1.30 & 1.33 & 1.32 \\
\hline $\mathrm{SE}(\mathrm{d}) \pm$ & 0.04 & 0.04 & 0.05 & 0.03 & 0.03 & 0.03 & 0.03 & 0.03 & 0.02 & 0.01 & 0.01 & 0.01 & 0.02 & 0.02 & 0.02 \\
\hline $\mathrm{CD}(\mathrm{p}=0.05)$ & 0.07 & 0.07 & 0.10 & 0.07 & 0.07 & 0.05 & 0.06 & 0.06 & 0.04 & 0.03 & 0.03 & 0.02 & 0.05 & 0.05 & 0.05 \\
\hline
\end{tabular}

\section{Potassium content}

With advancement of crop growth, a progressive declined in $\mathrm{K}$ concentration was observed in rice in both the years. The result was also supported by Shahi et al. (2017) ${ }^{[20]}$; Latha et al. (2019) ${ }^{[13]}$ and Meetei et al. (2019) ${ }^{[15]}$. The decline in K content might be due to dilution effect, caused by higher dry matter production, low $\mathrm{K}$ status of soil and fixation of applied $\mathrm{K}$ (Shahi et al., 2017) ${ }^{[20]}$. Application of either inorganic, organic or their combinations found the significantly higher $\mathrm{K}$ content in rice over control. This might be due to slow release of nutrients from organic sources thereby increasing $\mathrm{K}$ in soil along with inorganic source during the growing stage and made it available throughout the growing period (Baitilwake et al., 2012 and Meetei et al., 2019) [3, 15]. Comparing the different treatments, significantly higher $\mathrm{K}$ content was recorded in $T_{12}$ on 30 DAT; $T_{12}, T_{11}$ and $T_{7}$ on 60 and $T_{11}$ on 90 DAT. However, at the time of harvest, $\mathrm{T}_{12}$ noted the highest $K$ concentration in grain followed by $T_{11}$ and $T_{7}$ while $\mathrm{K}$ content in straw was highest in both the treatments $T_{11}$ and $\mathrm{T}_{12}$ showing parity with $\mathrm{T}_{5}, \mathrm{~T}_{6}$ and $\mathrm{T}_{10}$. In contrary to $\mathrm{P}$ content, the $\mathrm{K}$ content recorded in grain was low under different treatments.

\section{Conclusion}

From the experimental results, it can be concluded that that integrated nutrient management practices significantly increased higher dry matter production grain yield and NPK content in rice. $75 \%$ RDN from urea $+25 \%$ RDN from FYM +10 tonnes Azolla ha $^{-1}$ could be considered as a better option for achieving higher productivity of rice under transplanted condition.

\section{References}

1. Aditya KS, Kushwaha HS. An evaluation of chickpea (Cicer arietinum) crop yield through nutrient management in dry land condition of Bundelkhand (UP), India. International Journal of Current Microbiology and Applied Sciences. 2018; 7(05):254-258.

2. Azam F. Comparative effects of organic and inorganic nitrogen sources applied to a flooded soil on rice yield and availability of nitrogen. Plant and Soil. 1990; 125:255-262.

3. Baitilwake MA, Salomez J, Mrema JP, Neve SD. Nitrogen mineralization of two manures as Influenced by Contrasting Application Methods under Laboratory conditions. Communication in Soil Science and Plant Analysis. 2012; 43(1-2):357-367.

4. Bar TA, Yermiyahu U, Beraud J, Keinan M, Rosenberg R, Zohar D et al. Nitrogen, phosphorus and potassium uptake by wheat and their distribution in soil following successive annual compost applications. Journal of Environmental Quality. 2004; 33(5):1855-1865.

5. FAO. Selected indicators of FAO in Asia-Pacific region corporate document repository; Food and Agriculture Organization, 2004.

6. FAO. Rice Market Monitor: Food and Agriculture Organization (FAO) of the United Nations. Rome, Italy, 2018.

7. Helgason BL, Larney FJ, Janzen HH, Olson BM. Nitrogen dynamics in soil amended with composted cattle manure. Canadian Journal of Soil Science. 2007; 87(1):43-50.

8. Husan MR, Islam MR, Faried K, Mian MH. Nitrogen use efficiency and rice yield as influenced by the application of prilled urea and urea super granule with or without organic manure. Journal of Bangladesh Agricultural University. 2014; 12(1):37-43.

9. Islam MS, Paul AK, Bari F, Shahriar S, Sultana MS, Hosain MT. Integrated effect of organic manures and nitrogen on yield contributing characters and yield of rice (BRRI dhan29). International Journal of Science and. Research. 2014; 4(11):1-6.

10. Jackson ML. Soil Chemical Analysis. Prentice Hall of India Pvt. Ltd., New Delhi, 1973.

11. Jeyajothi R, Durairaj SN. Influence of integrated nutrient management practices on dry matter production, yield and NPK uptake of transplanted rice (Oryza sativa). Jornal of Applied Natural Science. 2016; 8(2):574-578.

12. Kumar V, Singh HR, Srivastava VK, Sharma R, Pant N, Tomar PK. Nitrogen release pattern of different organic 
sources under varying levels of NPK fertilizers and their effect on yield and nutrient uptake in hybrid rice-wheat cropping system. Journal of Pharmacognogy and Phytochemistry. 2018; SP1:618-623.

13. Latha M, Ratna Prasad P, Prasad PRK, Lakshmipathy R, Srinivasarao V. Effect of integrated nitrogen management on macronutrient content and uptake by rice crop. International Journal Chemistry Studies. 2019; 7(1):1107-1112.

14. Liu D, Zhu Z. Effect of available phosphorus in paddy soils on phosphorus uptake of rice. Journal of Radio Analytical Nuclear Chemistry. 1996; 205(2):235-243.

15. Meetei WH, Singh RK, Devi NS, Devi TS. Effect of integrated nitrogen management on macronutrient content in rice. International Journal of Chemical Studies. 2019; 7(3):5173-5176.

16. Nongmeikapam G, Devi NS. Effect of Organic Manures and Humic Acids on Nitrogen Concentration and Yield of Chickpea (JG-16). International Journal of Chemical Studies. 2018; 6(5):2707-2711.

17. Sahu YK, Chaubey AK, Mishra VN, Rajput AS, Bajpai RK. Effect of integrated nutrient management on growth and yield of rice (Oryza sativa L.) in inceptisol. Plant Archives. 2015; 15(2):983-986.

18. Satish A, Hugar AY, Kusagur N, Chandrappa H. Effect of integrated nutrient management on soil fertility status and productivity of rice-maize sequence under permanent plot experiment. Indian Journal of Agricultural Research. 2011; 45(4):320-325.

19. Shah RA, Kumar S. Effect of integrated nutrient management on vegetative growth and yield of transplanted hybrid rice (Oryza sativa L.) crop. International Journal of Agricultural and Crop Sciences. 2014; 7(11):863-869.

20. Shahi UP, Deepak Prajapati, Dhyani BP, Tomar SS, Ashok Kumar, Ashish Dwivedi. Effect of balance potassium management on performance of Basmati Rice in rice-potato- maize cropping system of western Uttar Pradesh, India, International Journal of Current Microbiology and Applied Sciences. 2017; 4:147-155.

21. Shinde SE, More SS, Gokhale NB, Patil KD. Evaluation of the rice hybrids grown under different INM practices for primary nutrients content and yield under lateritic soil of south konkan. International Journal of chemical Studies. 2017; 5(6):970-975.

22. Singh YV, Mandal BK. Nutrition of rice (Oryza sativa) through Azolla, organic materials and urea. Indian Journal of Agronomy. 1997; 42(2):626-633.

23. Sohel MH, Sarker A, RazzakMd A, Hashem, Md A. Integrated use of organic and inorganic fertilizers on the growth and yield of Boro rice (cv. BRRI dhan 29). Journal of Bioscience and Agricultural Research. 2016; 10(01):857-865. 